Original Paper

\title{
Diversifikasi Pengembangan Tanaman Tumpangsari dengan Budidaya Rumput Laut untuk Meningkatkan Pendapatan Masyarakat di Teluk Ekas Lombok Timur
}

\author{
Eka S. Prasedya ${ }^{1}$, Ahmad Jupri ${ }^{1}$, Anggit L. Sunarwidhi ${ }^{2}$, Bq T. Khairina Ilhami ${ }^{1}$, \\ Angga S. Abidin' ${ }^{1}$, Sri Widyastuti ${ }^{3}$, Sunarpi ${ }^{1 *}$ \\ ${ }^{1}$ Pusat Unggulan Biosain dan Bioteknologi FMIPA Universitas Mataram, Jl. Majapahit 62 Mataram \\ 83125, Indonesia \\ ${ }^{2}$ Program Studi Farmasi, Fakuktas Kedokteran Universitas Mataram, Jl. Majapahit 62 Mataram 83125 \\ Indonesia \\ ${ }^{3}$ Fakuktas Teknologi Pangan dan Agroindustri, Universitas Mataram, Jl. Majapahit 62 Mataram 83125 \\ Indonesia.
}

DOI: $\underline{10.29303 / \text { jpmpi.v3i1.452 }}$

Sitasi: Prasedya, E., Jupri, A., Sunarwidhi, A., Ilhami, B., Abidin, A., Widyastuti, S., \& Sunarpi, S. (2020). Diversifikasi Pengembangan Tanaman Tumpangsari dengan Budidaya Rumput Laut untuk Meningkatkan Pendapatan Masyarakat di Teluk Ekas Lombok Timur. Jurnal Pengabdian Magister Pendidikan IPA, 3(1). doi:https://doi.org/10.29303/jpmpi.v3i1.452

*Corresponding Author: Sunarpi; Pusat Unggulan Biosains dan Bioteknologi FMIPA Universitas Mataram, Lombok, Nusa Tenggara Barat, Indonesia. Email: ekajp@yahoo.com

\begin{abstract}
Abstrak: Eucheuma cottonii dan Eucheuma striatum, merupakan rumput laut bernilai ekonomi timggi, yang disebabkan oleh kandungan karaginannya, senyawa hidrokoloid yang merupakan bahan baku industri pangan dan farmasi. Meskipun demikian, budidaya rumput laut tersebut belum dapat meningkatkan pendapatan pembudidaya rumput laut di Teluk Ekas Lombok Timur. Hal ini disebabkan karena rumput laut dipanen pada umur sekitar 30 hari, yang menyebabkan rendemen, kadar karaginan dan harga jual per kilogram kering rendah yang pada akhirnya pendapatan pembudidaya rumput laut menjadi rendah. Karena itu, perlu adanya diversifikasi usaha untuk meningkatkan pendapatan masyarakat di Teluk Ekas. Artikel ini melaporkan pelatihan diversifikasi tanaman tumpangsari dengan budidaya Eucheuma cottonii dan Eucheuma striatum di Teluk Ekas Lombok Timur. Pembudidaya rumput laut diajarkan menanam tanaman tumpangsari cabe, jagung manis dan bayam, yang umurnya panjang (satu tahun), menengah (2 bulan) dan pendek ( 2 minggu). Kegiatan ini, dapat menambah penghasilan pembudidaya dalam jangka pendek, jangka menengah dan jangka panjang, serta rumput lautnya dipanen pada umur minimal 45 hari, mutunya bagus dan harga jualnya mencapai 20.000 rupiah per kilogram kering. Dengan demikian, akhirnya kegiatan yang dilakukan secara berkesinambungan ini, diharapkan dapat meningkatkan pendapatan masyarakat pembudidaya rumput di Teluk Ekas Lombok Timur.per kilogram berat kering menjadi 22.000 rupiah per kilogram berat kering.
\end{abstract}

Kata Kunci: Diversifikasi; tanaman tumpangsari; Eucheuma cottonii; Eucheuma striatum; pendapatan masyarakat. 


\section{Pendahuluan}

Makroalga, yang sehari-hari dikenal dengan nama rumput laut merupakan salah satu komoditi rumput laut bernilai ekonomi tinggi. Hal ini disebabkan karena rumput sebagai penghasil senyawa hidrokoloid, seperti karaginan, agar dan alginat, yang merupakan bahan baku industri pertanian, pangan dan farmasi (Suparmi dan Sahri, 2009). Eucheuma cottoni dan Eucheuma striatum, yang dikenal sebagai alga merah dan alga hijau, sehari-hari dikenal dengan nama cottonii dan sakol, merupakan rumput laut penghasil karaginan, dan masuk di dalam karaginofita (penghasil karaginan) (Ismal et al., 2018).

$$
\text { E. cottoni dan E. striatum (sakol) }
$$
merupakan dua jenis rumput laut yang populer dibudidayakan oleh pembudidaya rumput laut di Nusa Tenggara Barat, termasuk di daerah sentra produksi rumput laut Teluk Ekas, Kabupaten Lombok Timur. Harga rumput laut kering kedua jenis tersebut bervariasi dari 12.000-22.000 rupiah per kilogram berat kering rumput laut, sangat tergantung pada kualitas rumput yang dihasilkan oleh pembudidaya. Rumput laut memiliki pasar pada setiap level umur panen. Rumput laut yang dipanen pada umur 2 minggu (14 hari), dapat dijual sebagai bibit dengan harga sekitar 5000 rupiah per kilogram basah rumput laut, yang tentu akan digunakan sebagai bibit rumput laut.

Selain umur 14 hari, pembudidaya rumput laut di NTB umumnya memanen rumput lautnya pada umur 30 hari, lebih pendek dari umur panen rumput laut di Filipina, sekitar 60 hari (Ortago E., 2005). Faktor utama penyebab panen umur 30 hari, karena pembudidaya rumput laut yang memiliki satu bidang usaha ini membutuhkan dana untuk memenuhi kebutuhan sehari-hari. Rumput laut yang dipanen pada umur 30 hari memiliki rendemen sekitar 15-20\%, kadar karaginan rendah dan kekerasan gelnya juga rendah, sehingga harga jualnya juga rendah, sekitar 12.000-14.000 rupiah per kilogram berat kering rumput laut. Kondisi ini tentu menjadi penyebab rendahnya pendapatan pembudidaya rumput laut di Teluk Ekas, dan daerah sentra produksi rumput laut lainnya di NTB.

Karaginan sebagai faktor penting penentu mutu rumput laut membutuhkan waktu minimal 45 hari dalam proses biosintesis dan penimbunannya oleh rumput laut (Sunarpi et al., 2005). Kondisi inilah yang menyebabkan panen cottonii di Filipina sekitar 60 hari (Ortago E., 2005), supaya deposisi karaginan menjadi maksimal, dan mutu rumput laut yang dihasilkan berstandar mutu ekspor dengan harga jual sekitar 22.000 rupiah per kilogram berat kering rumput laut. Persoalan mendasar pembudidaya rumput laut di NTB sebagian besar tergolong bertaraf ekonomi rendah yang sangat membutuhkan dana untuk memenuhi kebutuhannya seharihari. Dengan kondisi itu, maka masa tunggu 45 hari umur panen, apalagi 60 hari, dihadapkan pada persoalan dana untuk memenuhi kebutuhan sehari-hari. Akibatnya, rumput laut dipanen pada usia muda, 14-30 hari, meskipun dengan harga jual yang rendah.

Berdasarkan kenyataan itu, maka perlu ada upaya untuk penganeka ragaman usaha budidaya rumput dengan usaha lain, seperti pertanian tumpangsari dan usaha lainnya, sehingga dapat memoeroleh uang segar untuk menutupi kebutuhan sehari-hari dalam masa tunggu panen rumput laut, baik dalam masa 45 hari, atau masa 60 hari. Dengan cara seperti itu, pembudidaya membiarkan rumput lautnya tumbuh sampai umur panen 45 hari, kualitas rumput lautnya meningkat, dan harga jualnya juga menjadi naik. Dengan pendekatan itu, pendapatan pembudidaya rumput laut menjadi meningkat, yang bersumber dari hasil pertanian dan hasil rumput laut itu sendiri.

Artikel ini melaporkan pelatihan tumpangsari tanaman dengan budidaya rumput laut Eucheuma cottonii dan Eucheuma striatum dalam rangka untuk meningkatkan pendapatan pembudidaya rumput di Teluk Ekas Lombok Timur. Pembudidaya rumput laut dilatih bercocok tanam tumpang sari cabe 
rawit (berumut setahun), jagung manis (berumur 2 bulan) dan bayam (14 hari), yang pada saat bersamaan diajarkan budidaya Eucheuma cottonii dan Eucheuma striatum. Kegiatan ini dikakukan dalam bentuk demontrasi langsung di lokasi pengabdian, sehingga pembudidaya langsung mempraktekkan. Pendampingan yang secara berkelanjutan ini diharapkan dapat meningkatkan pendapatan pembudidaya rumput laut, yang bersumber dari hasil tanaman pertanian, dan juga dari hasil rumput laut.

\section{Metode Pelaksanaan}

Pelatihan yang diikuti dengan demplot dilakukan dengan tahapan sebagai berikut:

1) Penjelasan pentingnya umur panen terhadap mutu rumput laut.

Pelatihan diikuti oleh dua kelompok pembudidaya yang sudah dibentuk, yang masing-masing lima orang, sehingga keseluruhan peserta berjumlah 10 orang. Kelompok yang sudah terbentuk diberikan penjelasan pengaruh umur panen terhadap berat kering dan kadar karaginan Eucheuma cottonii dan Eucheuma striatum hasil penelitian Sunarpi dkk (2005), sebagai ditunjukkan pada grafik di bawah ini.

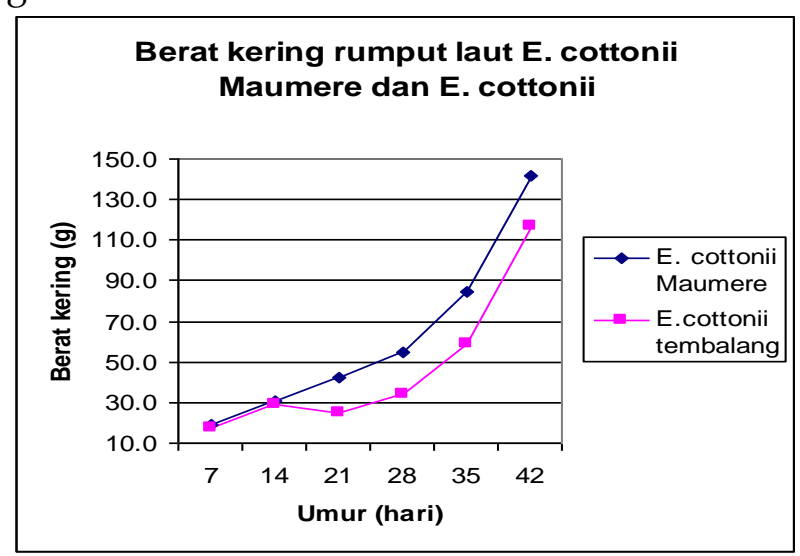

Gambar 1. Pengaruh umur panen terhadap berat kering Eucheuma cottonii Maumere dan Eucheuma cottonii Tembalang, yang menunjukkan pertumbuhan maksimal dicapai pada umur 45 hari (Sunarpi et al., 2005)

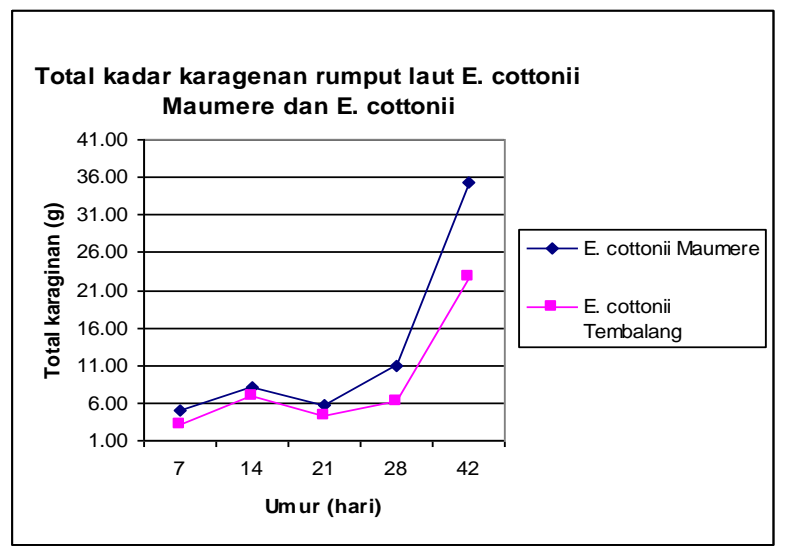

Gambar 2. Pengaruh umur panen terhadap kadar karaginan Eucheuma cottonii Maumere dan

Eucheuma cottonii Tembalang, yang menunjukkan kadar karaginan maksimal dicapai pada umur 42 hari

2) Penanaman rumput laut Eucheuma cottoni dan Eucheuma striatum dengan metode rakit apung

Setiap orang dari anggota kelompok pembudidaya menanam Eucheuma cottoni pada 3 rakit apung, dan Eucheuma striatum pada 2 rakit apung lainnya, sehingga setiap orang dari 10 orang anggota kelompok menanam rumput laut pada 5 rakit apung, sehingga total rakit apung pada demplot ini berjumlah 50 rakit apung.

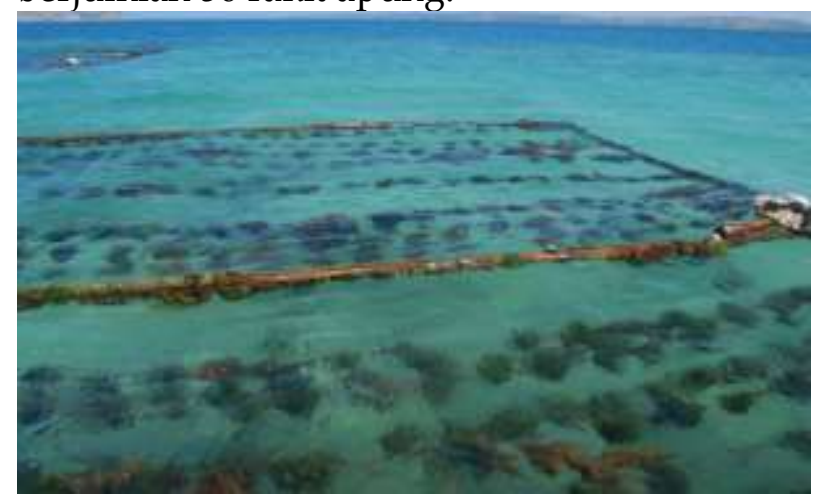

Gambar 3. Penanaman Eucheuma cottonii dan Eucheuma striatum dengan metode rakit

3) Penanaman cabe rawit, jagung dan bayam secara tumpang sari

Demplot tanaman cabe, jagung dan bayam dilakukan pada kawasan sekitar 20 are, sehingga masing-masing anggota kelompok merawat ketiga jenis tanaman yang ditumpangsari pada luasan sekitar 2 are. 
Mereka diajari pengolahan tanah, penanaman dan cara perawatan tanaman sampai panen.

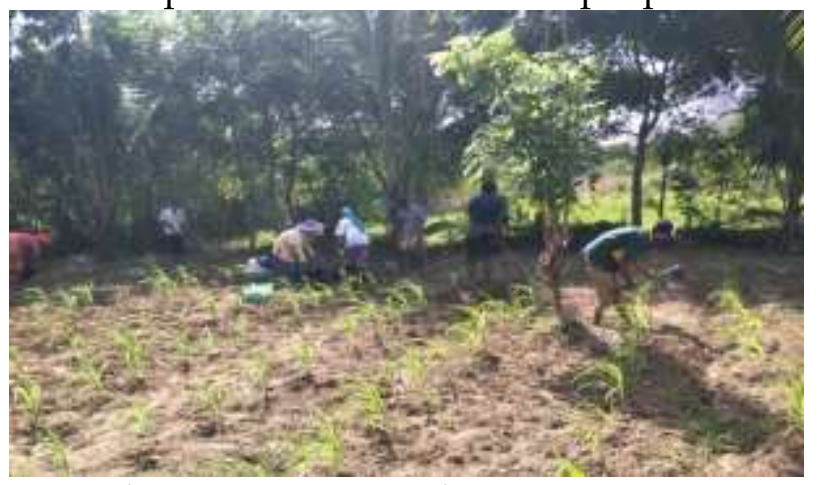

Gambar 4. Penanaman cabe rawit, jagung manis dan bayam secara tumpangsari

\section{Hasil dan Pembahasan}

Penjelasan pengaruh umur panen terhadap berat kering dan kadar karaginan Eucheuma cottonii dan Eucheuma striatum diikuti oleh 10 orang anggota kelompok. Mereka menyadarinya sengan sangat antusias, dan baru menyadari bahwa umur panen mempengaruhi berat kering dan kadar karaginan yang pada akhirnya mempengaruhi harga jual rumput laut per kilogram berat kering rumput laut dan pendapatan pembudidaya rumput laut.

Setelah mendapat penjelasan akan pentingnya umur panen terhadap berat kering, kadar karaginan, dan harga jual rumput laut, maka pembudidaya mempraktekkan pemahaman tersebut dengan menanam Eucheuma cottonii dan Eucheuma striatum dengan metode rakit apung dengan pendampingan tim pengabdian darinUniversitas Mataram. Penanaman telah dilakukan sejak tanggal 8 Juni-22 juli 2020. Sampling dikakukan pada umur 7, 14, 21, 28, 35 , dan 42 hari, serta berat basah per rakit ditimbang pada umur 45 hari. Selanjutnya semua sampel dikeringkan dan ditimbang berat kering, dianalisis kadar karaginan dan kekerasan gel yang dihasilkan. Dengan praktek secara langsung tersebut, pembudidaya dapat mengetahui dan melihat secara langsung pengaruh umur panen terhadat berat basah, berat kering, rendemen, kadar karaginan dan harga jual rumput laut yang dihasilkan.

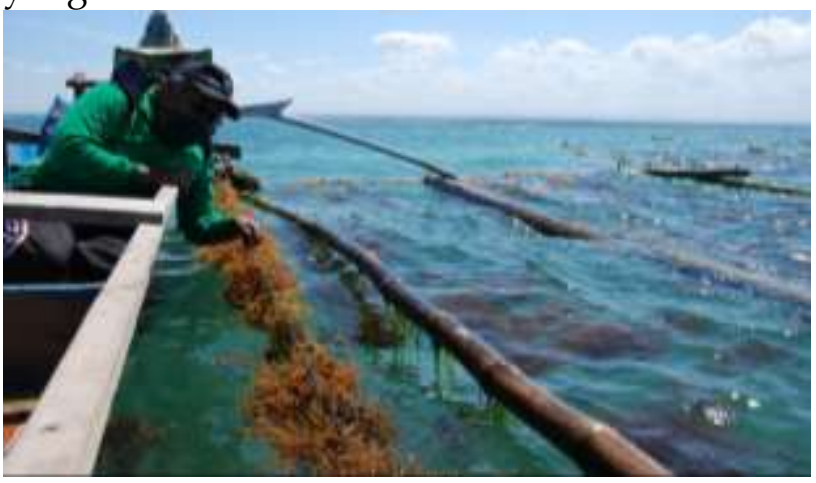

Gambar 5. Sampling Eucheuma cottonii dan

Eucheuma striatum pada rakit yang dilakukan setiap minggu sekali dari umur 7 hari sampai umur 42 hari

Pelatihan yang diikuti dengan praktek langsung tersebut diharapkan dapat menumbuhkan kesadaran akan pentingnya umur panen bagi harga jual rumput laut, dengan harapan pembudidaya mempraktekkan apa yang diajarkan tersebut pada musim tanam berikutnya, sehingga secara mandiri pembudidaya dapat meningkatkan mutu rumput laut, harga jual rumput laut, yang oada akhirnya dapat meningkatkan pendapatan pembudidaya rumput laut di Teluk Ekas.

Setelah pembudidaya selesai melakukan penanaman rumput sebagaimana yang telah diajarkan, maka pembudidaya melanjutkan dengan pengolahan lahan sekitar 20 are, untuk penanam cabe rawit, jagung manis dan bayam secara tumpang sari, sebagaimana ditunjukkan pada gambar 6 di bawah ini.

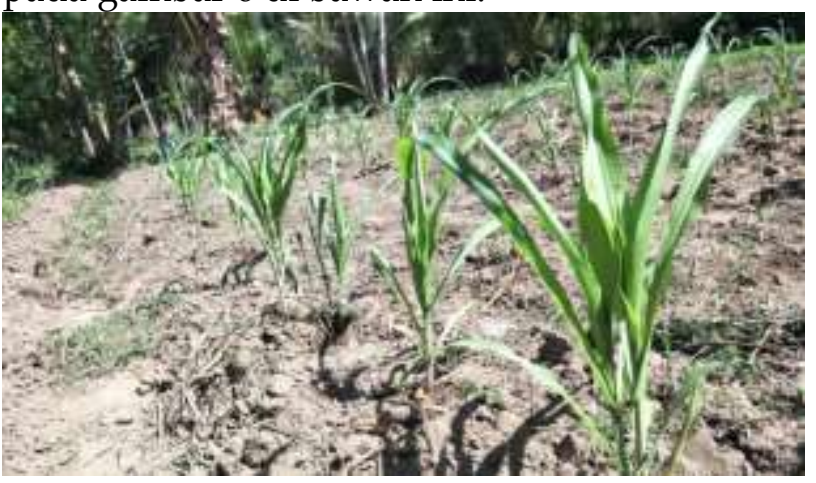

Gambar 6. Pengolahan tanah dan penanaman cabe, jagung manis dan bayam. 
Penanaman dilakukan secara bertahap, dimulai dengan penanaman jagung, dilanjutkan dengan penanaman cabe rawit seminggu kemudian, serta benih bayam ditabur terakhir pada minggu ketiga. Pengaturan tanam seperti itu, bayam dipanen pertama, disusul dengan jagung dan bace rabit. Mengingat tanaman cabe merupakan tanaman dua musim tanam, maka setelah bayam dan jagung dipanen, tanam cabe rawit masih terus tumbuh dan produksi untuk masa satu tahun. Karena itu, masih memungkinkan untuk ditumpang sarikan tanaman baru yang berumur pendek, dehingga dalam masa tunggu 45 hari rumput laut selalu ada hasil tanaman yang dijual untuk memenuhi kehidupan sehari-hari.

Hasil pelatihan yang dibarengi dengan demplot ini, baik untuk rumput laut maupun tanaman, diharapkan pembudidaya rumput laut mendapatkan penghasilan dari hasil pertanian dalam masa tunggu rumput 45 hari. Akibatnya pembudidaya rumput laut tidak perlu menjual rumput lautnya pada usia muda dan dibiarkan tumbuh selama 45 hari, sehingga rumput laut yang dihasilkan berkualitas dan memikiki harga jual tinggi. Dengan demikian, pembudidaya rumput laut memiki dua sumber penghasilan, hasil tanaman dan hasil penjualan rumput laut yang keduanya meningkatkan pendapatan pembudidaya rumput laut di Teluk Ekas Lombok Timur.

\section{Kesimpulan}

Berdasarkan hasil pelatihan dan demplot tumpangsari tanaman dan budidaya rumput laut E. cottonii dan E. striatum di Teluk Ekas Lombok Timur dapat disimpulkan bahwa kegiatan tersebut selain berhasil memberikan pemahaman akan pentingnya umur panen terhadap kualitas rumput laut yang dihasilkan juga pembudidaya menyadari perlu adanya usaha sampingan seperti budidaya tanaman secara tumpang sari. Kesadaran masyarakat terhadap hal tersebut diatas juga terbukti dengan keinginan masyarakat untuk melakukan budidaya tanaman secara tumpang sari pada saat bersamaan dengan budidaya rumput laut. Kegiatan seperti ini perlu dipantau dampaknya pada kurun waktu yang lebuh panjang dalam beberapa musim tanam rumput laut sehingga dampak kegiatan tersebut berupa peningkatan kualitas dan harga jual rumput laut yang pada akhirnya akan meningkatkan pendapatan masyarakat dapat diamati dengan jelas.

\section{Ucapan Terimakasih}

Penulis mengucapkan terimakasih kepada dewan DRIN riset dan inovasi Kemenristek RI yang telah menyediakan anggaran pengabdian masyarakat PPDM tahun 2020, rektor Universitas Mataram dan seluruh pihak yang telah berpartisipasi dan berkontribusi selama kegiatan berlangsung, terutama kelompok masyarakat pembudidaya rumput laut di Teluk Ekas, Lombok Timur.

\section{Daftar Pustaka}

Ismal, M., Wijaya, M., \& Kadirman. 2018. Pengaruh Jarak Tanam Pada Budidaya Rumput Laut (Eucheuma cottonii) Terhadap Spesifikasi Mutu Karaginan. Jurnal Pendidikan Teknologi Pertanian. 4: S242-s249.

Ortago, E. (2005). Seaweed Cultivation in NTB.

Proceeding on International Seaweed Forum. Clarion Hotel, Makassar. Indonesia.

Sunarpi., Jupri, A., Gazali, M., \& Nikmatullah, A. (2005). Seaweed Cultivation in NTB. Proceeding on International Seaweed Forum. Clarion Hotel, Makassar. Indonesia.

Suparmi \& Sahri, A. (2009). Mengenal Potensi Rumput laut: Kajian Pemanfaatan Sumber Daya Rumput Laut dari Aspek Industri dan Kesehatan. Sultan Agung. XLIV (118): 95-116. 